\title{
EFFECT OF ADDITIONAL LEAF EXTRACT OF CIPLUKAN (Physalis angulata L) ON FEED ON THE GROWTH PERFORMANCE OF tilapia (Oreochromis niloticus)
}

\author{
Suaebatul Aslamiah ${ }^{1 *}$, Muhammad Marzuki ${ }^{1}$, Fariq Azhar ${ }^{1}$ \\ ${ }^{1}$ Aquaculture Study Program, University of Mataram \\ Jl. Pendidikan No. 37 Mataram. NTB.
}

*Correspondence:
arel_natasya@yahoo.co.id

Received : 2021-12-21

Accepted : 2021-12-22

Keywords :

Tilapia, ciplukan leaves, growth.

\begin{abstract}
The purpose of this study is to determine the effect of the effectiveness of the addition of ciplukan leaf extract (Physalis angulata L.) on feed to the growth performance of tilapia (Oreochromis niloticus). This research method uses a Complete Randomlzed Design (RAL). This study consisted of 4 treatments and 3 replays, so 12 experimental units were used. Dose treatment on PO (feed without the addition of ciplukan leaf extract), P1 (Feed added ciplukan leaf extract with a dose of 4\%), P2 (Feed added ciplukan leaf extract with a dose of $8 \%$ ), and P3 (Feed added ciplukan leaf extract with a dose of $12 \%)$. This dosage treatment is based on Effendi \&Hardi research (2014) with dose treatment of $4 \%, 8 \%$, and $12 \%$ per $1 \mathrm{~kg}$ of feed. the addition of ciplukan leaf extract with a concentration of $8 \%$ in feed provides absolute weight growth of (37.39 \pm 20.33$)$, survival rate of $(83.33 \pm 0.98)$, daily growth rate $(1.25 \pm 0.60)$, and feed utilization efficiency of $(4.67 \pm 0.58)$ and tend to be higher than other treatments.
\end{abstract}

\section{INTRODUCTION}

Freshwater fish is one type of fish that is widely consumed by the community. According to the KKP (2018) in 2021, the need for freshwater fish is estimated to reach 172 million tons. This need has increased by $15 \%$ from the average requirement so far. Tilapia (Oreochromis niloticus) is one of the freshwater fish that has a good market prospect. This fish has beneficial properties such as easy to breed and relatively faster growth. The advantages of this tilapia cause this fish to be widely cultivated and has a high market demand. The high demand for tilapia causes farmers to apply intensive aquaculture systems to increase the amount of tilapia production (Pasaribu et al., 2015).

Intensive tilapia cultivation has been widely developed but is still experiencing various problems, namely frequent disease outbreaks and low survival rates. The decrease in water quality causes the fish's appetite to decrease so that fish growth becomes slow. In addition, declining water quality can also cause fish to be susceptible to disease so that their survival is low. The decrease in water quality in fish culture media is caused by the presence of waste formed from the remains of uneaten fish feed and fish waste. In intensive fish farming, only $25 \%$ of the feed given can be converted as a product of production and the rest is wasted as waste (62\% in the form of dissolved materials and $13 \%$ in the form of precipitated particles) (Suryaningrum, 2014). 
Journal of Fish Health Vol. 1 (2) - Dec 2021

Aslamiah et al. (2021)

https://doi.org/10.29303/jfh.v1i2.533

Ciplukan leaf ( Physalis angulata L.) is one of the genera of Physalis which is one of the medicinal plants. Ciplukan leaves are easy to obtain, but the use of ciplukan leaves is still not widely known by the public. Ciplukan leaves can be processed into ciplukan leaf extract. Ciplukan leaf extract is known to contain flavonoids, polyphenols (tannins), saponins, alkaloids, quinones and triterpenoid steroids. Ciplukan leaves are still not widely used properly because of the nutritional content that needs to be improved to become quality raw materials for alternative fish feed. Improvement of feed quality is one way that can be done by spraying extracts on feed, where these compounds are classified as secondary metabolites. These secondary metabolites have antibacterial properties, protein denaturation and prevent bacterial digestion, as well as antimicrobial and antiviral properties (Rohyani 2015). And compounds such as saponins, flavonoids and polyphenols which are very good for fish feed because they increase appetite and immunity to disease (Setiawan, 2009).

Based on the statement above, it is necessary to conduct research on the effectiveness of adding ciplukan leaf extract (Physalis angulata L.) to feed for the growth performance of tilapia (Oreochromis niloticus). The purpose of this study was to determine the effect of the addition of ciplukan leaf extract (Physalis angulata L.) in feed on the growth performance of tilapia (Oreochromis niloticus).

Time and place

\section{METHODOLOGY}

This research was held for 30 days in August-November 2020 at the Laboratory of Aquaculture, Faculty of Agriculture, University of Mataram.

Tools and materials

The tools used in this study were a $28 \mathrm{~cm} \times 30 \mathrm{~cm} \times 40 \mathrm{~cm}$ container, blower, aeration hose, aeration stone, ruler, and analytical balance. The materials used in this study were tilapia with a size of 3-5 cm, fresh water, ciplukan leaves, and pelleted feed.

\section{Research design}

The design used was a completely randomized design (CRD) consisting of 4 treatments with 3 replications, so that 12 experimental units were obtained. The treatment with the dose given was based on research by Effendi \& Hardi (2014) with doses of 4\%, 8\%, and $12 \%$ per 1 $\mathrm{kg}$ of feed. The treatment given is as follows:

PO : (feed without the addition of ciplukan leaf extract);

P1 : (The feed added with ciplukan leaf extract at a dose of $4 \%$ );

P2 : (The feed added with ciplukan leaf extract at a dose of 8\%);

P3 : (Feed with added ciplukan leaf extract at a dose of 12\%).

\section{Research procedure}

The ciplukan leaves used in this study were young leaves. The leaves were collected, washed, and then drained. Leaf drying was carried out by airing for 5 days. The dried leaves are then crushed and filtered to obtain a fine powder (simplicia). The manufacture of ciplukan leaf extract was carried out by meserasi by soaking simplicia in $96 \%$ alcohol, for 3 days. Simplicia was filtered after 3 days. The extract obtained was evaporated using a rotary evaporator. efenCiplukan alcohol extract was made in doses of $4 \%(\mathrm{v} / \mathrm{v}), 8 \%(\mathrm{v} / \mathrm{v})$, and $12 \%$ $(\mathrm{v} / \mathrm{v})$ (Effendi \& Harti, 2014). Making a dose of $4 \%(\mathrm{v} / \mathrm{v})$ of ciplukan leaves is to dissolve $1 \mathrm{~mL}$ of liquid extract of ciplukan leaves into distilled water up to $25 \mathrm{~mL}$. Extracts with doses of $8 \%$ 
Journal of Fish Health Vol. 1 (2) - Dec 2021

Aslamiah et al. (2021)

https://doi.org/10.29303/jfh.v1i2.533

$(\mathrm{v} / \mathrm{v})$ and $12 \%(\mathrm{v} / \mathrm{v})$ were carried out in the same way, namely by dissolving $2 \mathrm{~mL}$ and $3 \mathrm{~mL}$ of liquid extract of ciplukan leaves in distilled water up to $25 \mathrm{~mL}$. Ciplukan uamg leaf extract is ready and then mixed into the feed.

Each container is filled with $10 \mathrm{~L}$ of water and equipped with one aeration stone. The test animals used were tilapia with a size of 3-5 cm which were stocked with a density of 10 fish/container. During the 30-day rearing, the test animals were fed $5 \%$ of the test animal biomass. Feed was given 2 times a day, namely at 07.00 and 16.00 WIB.

Research Parameters

Life sustainability

Fish survival was calculated using the survival rate formula according to Effendi (1979).

Description:

$$
\mathrm{SR}=\frac{N t}{N 0} x 100 \%
$$

SR : Survival Rate

$\mathrm{Nt} \quad$ : Final Number (tail)

No : Initial Number (tail)

Absolute Weight Growth

Absolute individual weight growth can be calculated by the formula Effendi (1997):

$\Delta \mathrm{W}=\mathrm{Wt}-\mathrm{Wo}$

Description:

W : Growth of absolute individual weight of test animals (grams)

Wt : Individual weight of fish at the end of the study (grams)

wow : Individual weight of fish at the beginning of the study (grams)

Daily growth rate

The daily growth rate was calculated by the Huisman (1987) formula.

Description:

$$
\mathrm{LPH}=\frac{\mathrm{I} n W t-\mathrm{I} n \mathrm{Wo}}{t} \times 100 \%
$$

Wt : Individual weight of fish at the end of the study (grams)

wow : Individual weight of fish at the beginning of the study (grams)

$\mathrm{T} \quad$ : Maintenance time (days)

Feed Utilization Efficiency

Feed utilization efficiency is calculated based on Tacon's (1987) formula:

Description:

$$
E P P=\frac{\mathrm{Wt}-\mathrm{W} 0}{\mathrm{~F}} \times 100 \%
$$

EPP : Feed utilization efficiency (\%)

Wt : Individual weight of fish at the end of the study (grams)

wow : Individual weight of fish at the beginning of the study (grams)

$\mathrm{F} \quad$ : Feed given during maintenance (grams)

Water quality

The water quality measured in this study included temperature, $\mathrm{DO}$ and $\mathrm{pH}$. Data were collected twice, namely in the first week of maintenance and the last week of maintenance. 
Journal of Fish Health Vol. 1 (2) - Dec 2021

Aslamiah et al. (2021)

https://doi.org/10.29303/jfh.v1i2.533

\section{Data analysis}

The data obtained from this study were analyzed with the MS program. Office Excel 2007 and for the ANOVA test were analyzed using the SPSS 21 program. Significantly different treatments were further tested with Duncan's follow-up test.

\section{Survival Rate}

\section{RESULT}

The results of observations of the survival rate of tilapia in the control treatment without the addition of ciplukan leaf extract and the addition of $8 \%$ ciplukan leaf extract resulted in survival rates that tended to be the same and tended to be higher than other treatments. Meanwhile, the addition of $4 \%$ and $12 \%$ ciplukan leaf extract resulted in the same survival rate but tended to be lower than the other treatments (Figure 1).

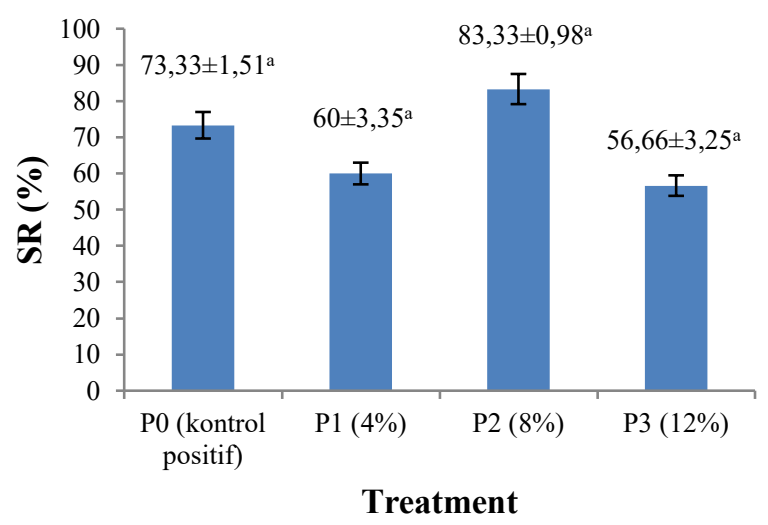

Figure 1. Tilapia survival rate

Description: P0 (Without Addition of Ciplukan Leaf Extract), P1 (Addition of Ciplukan Leaf Extract $4 \%$ ), P2 (Addition of Ciplukan Leaf Extract 8\%), P3 (Addition of Ciplukan Leaf Extract 12\%).

\section{Absolute Weight Growth}

The addition of ciplukan leaf extract to feed with different doses did not have a significant effect on the absolute weight growth of tilapia. However, the absolute weight growth of tilapia with the addition of $8 \%$ ciplukan leaf extract tended to be higher than the other treatments and tended to decrease with the addition of the ciplukan leaf extract, showing results that tended to be lower than the other treatments (Figure 2).

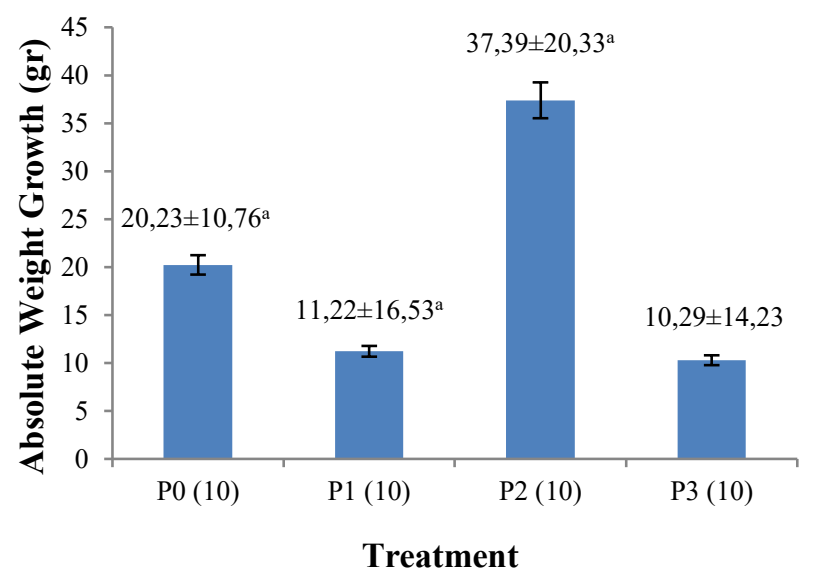

Figure 2. Growth in absolute weight of tilapia 
Journal of Fish Health Vol. 1 (2) - Dec 2021

Aslamiah et al. (2021)

https://doi.org/10.29303/jfh.v1i2.533

Description: P0 (Without Addition of Extract), P1 (Addition of Ciplukan Leaf Extract 4\%), P2 (Addition of Ciplukan Leaf Extract 8\%), P3 (Addition of Ciplukan Leaf Extract 12\%).

\section{Daily growth rate}

The daily growth rate was calculated by comparing the average weight at the beginning of the rearing with the average weight at the end of the rearing which is presented in Figure 3. After 30 days of rearing, it was shown that the daily growth rate of tilapia ranged from 0.34$1.25 \%$. The daily growth rate of P2 treatment was higher than the control treatment. Treatment P2 had the highest daily growth rate value (1.25\%), followed by control treatment $(0.67 \%)$, treatment $\mathrm{P} 1(0.37 \%)$ and treatment $\mathrm{P} 3(0.34 \%)$.

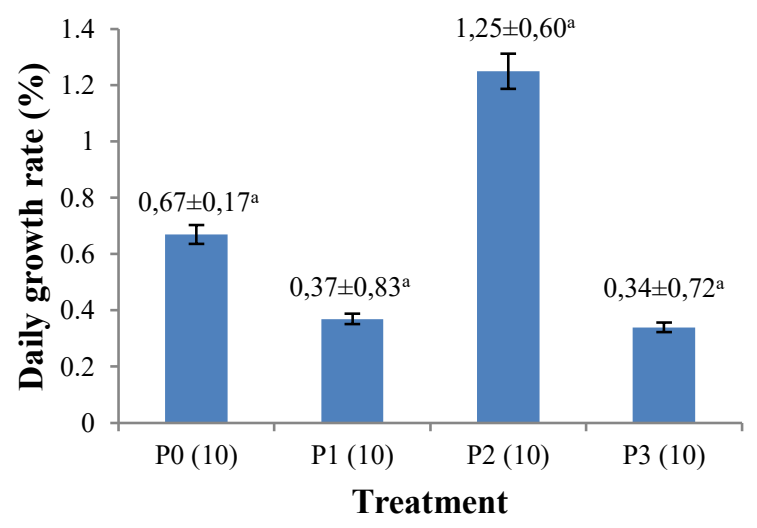

Figure 3. Daily Growth Rate of Tilapia.

Description: P0 (Without Addition of Ciplukan Leaf Extract), P1 (Addition of Ciplukan Leaf Extract 4\%), P2 (Addition of Ciplukan Leaf Extract 8\%), P3 (Addition of Ciplukan Leaf Extract 12\%).

\section{Feed Utilization Efficiency}

The addition of ciplukan leaf extract to feed did not have a significant effect $(P>0.05)$ on the efficiency of tilapia feed utilization. However, the feed efficiency of tilapia with the addition of $8 \%$ ciplukan leaf extract tends to be higher than the other treatments. In the treatment, the addition of $4 \%$ and $12 \%$ ciplukan leaf extract resulted in feed efficiency values which tended to decrease along with the increase in the addition of ciplukan leaf extract (Figure 4). However, this value tends to be lower than the control treatment without the addition of ciplukan leaf extract.

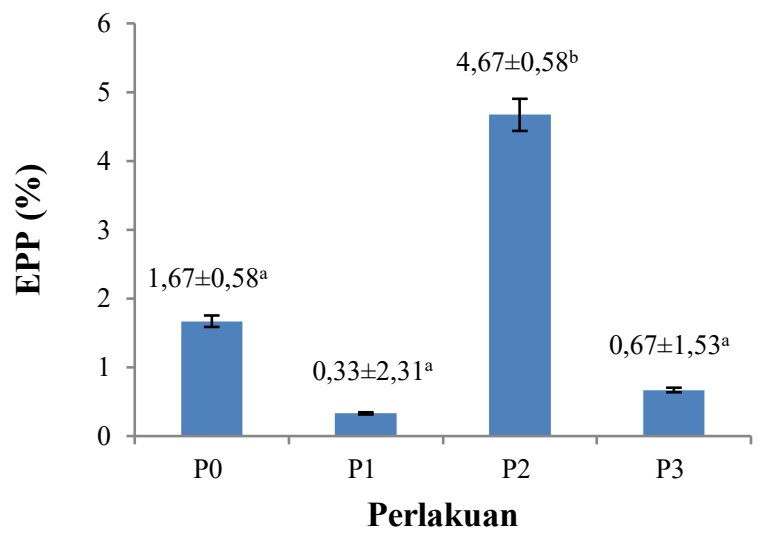

Figure 4. Efficiency of tilapia feed

Description: P0 (Without Addition of Ciplukan Leaf Extract), P1 (Addition of Ciplukan Leaf Extract 4\%), P2 (Addition of Ciplukan Leaf Extract 8\%), P3 (Addition of Ciplukan Leaf Extract 12\%). 
Journal of Fish Health Vol. 1 (2) - Dec 2021

Aslamiah et al. (2021)

https://doi.org/10.29303/jfh.v1i2.533

\section{Water quality}

During the study, water changes were carried out once a week and siphoning every two days on the maintenance media. The average range of water quality parameters during maintenance can be seen in table 1.

Table 1. Water quality during maintenance

\begin{tabular}{llllll}
\hline Parameter & P0 & P1 & P2 & P3 & Literature \\
\hline $\begin{array}{l}\text { Temperature } \\
\left({ }^{\circ} \mathrm{C}\right)\end{array}$ & $28,2-31,0$ & $28,5-30,6$ & $28,3-30,9$ & $28,8-30,7$ & $25-30^{*}$ \\
DO $(\mathrm{mg} / \mathrm{l})$ & $6,1-7,5-$ & $6,7-7,4$ & $6,0-6,9$ & $6,3-7,4$ & $4-7 * *$ \\
pH & $7,2-8,4$ & $6,9-8,3$ & $6,7-8,2$ & $7,0-8,3$ & $7,0-8,5 * * *$ \\
\hline
\end{tabular}

Description:

*) Suyanto (1994) in Trewavas (1982)

**) Kordi and Tancung (2005)

***) Ekubo and Abowei (2011).

\section{DISCUSSION}

Based on the results of the analysis, the addition of ciplukan leaf extract had a significantly different effect $(p<0.05)$ on the survival of tilapia. The survival of tilapia in P2 treatment had a significantly higher survival value than P0, P1 and P3. These results can explain that the addition of $8 \%$ ciplukan leaf extract can increase the survival value of tilapia. The high survival rate in P2 treatment, which was $83.33 \%$, was thought to be due to the addition of optimum ciplukan leaf extract in the feed. The survival rate of tilapia at P1 and P3 was lower when compared to P0 and P2, this is presumably due to the presence of high and low doses of ciplukan leaf extract that was given an adverse effect on the fish's body. Bandaranayake. (2006) in Yilmaz et al. (2011) stated that the effects of herbal plants may be related to toxic elements, high doses, and allergic conditions, but when used in the right dose it does not interfere with health. Where Physalis angulata $\mathrm{L}$. is proven as a plant that has anti-hyperglycemic, antibacterial, antiviral, immunostimulant and immunosuppressant, anti-inflammatory, antioxidant, and analgesic properties (Salgado et al., 2013). While the substances contained in ciplukan leaves such as saponins, flavonoids and polyphenols are very good for fish feed because they can increase appetite and immunity to disease and can be used to prevent fish stress (Setiawan, 2009). more fish increased, and aggressive movements and did not show fish stress and other symptoms.

The study of adding ciplukan leaf extract with different doses to feed did not have a significant effect on the absolute weight growth of tilapia. This indicates that the addition of ciplukan leaf extract in the test feed has not been able to provide a significant increase in the absolute weight growth of tilapia. The significant lack of absolute weight growth is thought to be due to the low activity of compounds in ciplukan leaf extract.

The absolute weight growth of tilapia reared for 30 days, positive control feed without the addition of ciplukan leaf extract (P0) and with the addition of $8 \%$ ciplukan leaf extract (P2) had an absolute weight which tended to be higher than the other treatments. This is presumably because the feed in the positive control (PO) of nutrients in the form of energy is used only for the maintenance of the body. Meanwhile, the $8 \%$ dose (P2) gave a significantly different response $(P<0.05)$ compared to the $4 \%(P 1)$ and $12 \%(P 3)$ doses. This response is due 
Journal of Fish Health Vol. 1 (2) - Dec 2021

Aslamiah et al. (2021)

https://doi.org/10.29303/jfh.v1i2.533

to the presence of active ingredients in the form of flavonoid compounds, saponins, and tannins in ciplukan leaf extract (Effendi \& Harti, 2014) where these compounds function by increasing the fish's immune system from disease attacks, and saponins work to increase membrane permeability when interactions occur. with bacterial cells, it causes the bacteria to lyse or break. Flavonoids can bind to proteins, so that it will interfere with the metabolic process of bacteria. Tannins can inhibit the growth of bacteria in low concentrations and in high concentrations can kill bacteria (Poeloengan and Praptiwi, 2010). Flavonoid compounds can be active at a temperature of $30^{\circ} \mathrm{C}$ (Susiani et al., 2017). Flavonoids will be optimally active at $\mathrm{pH} 8$ (Rismawati and Ismiyati, 2017). And at a dose of $8 \%$ (P2) it has the highest temperature of $30.9^{\circ} \mathrm{C}$ and the highest $\mathrm{pH}$ of 8.2 , so it can be said at this temperature that flavonoid compounds can be maximally activated as well as $\mathrm{pH}$.

At a low dose of $4 \%(P 1)$, the results were less than optimal to support its growth, meaning that with a small dose the expected effect could not be achieved, where the compounds contained were not maximally active even at a temperature of $30.6^{\circ} \mathrm{C}$ and did not have much effect. on the metabolic activity of fish. While at the highest dose which occupied the figure of $12 \%$ (P3), the results were less than optimal also for absolute weight growth, presumably because at a temperature of $30.7^{\circ} \mathrm{C}$ the active compound was not maximally activated and at too high a dose it turned into toxic (poison). According to (Ningrum et al., 2016) Alkaloid compounds are toxic to living things if used in high concentrations and higher amounts of saponins will be toxic (poisonous) and life threatening for certain animal species. Saponins with high concentrations will inhibit smooth muscle activity and form foam compounds so that they can hemolyze red blood cells which are strong poisons for fish and amphibians, so that the content of saponins that exceeds the dose limit that can be tolerated by fish can interfere with their growth (Rachman, et al, 2015). According to Puspaningsih (2003) in Rohyami (2008) that flavonoids have an acute toxicity effect on Artemia salina larvae. Tannin compounds when consumed in excessive amounts will inhibit the absorption of minerals such as iron (Ismarani, 2012).

Based on the graph, the results of observing the daily growth rate of tilapia during each treatment were P0 $(0.67 \%), \mathrm{P} 1(0.37 \%), \mathrm{P} 2(1.25 \%)$, and P3 $(0.34 \%)$ P2 has the highest growth compared to $\mathrm{P} 0, \mathrm{P} 1$, and $\mathrm{P} 3$. However, after the analysis test (ANOVA) on the daily growth rate was obtained $P>0.05$, this indicates that the daily growth rate of tilapia did not show a significant difference between treatments. This is probably due to the environmental carrying capacity, the age of the fish and the feed provided. This is supported by the opinion of Amri and Khairuman, (2008) which states that the body growth rate of cultivated tilapia depends on the physical and chemical effects of the waters and their interactions. on the results of the table test with a significance level of 0.005 from the $t$ table, it was found that the $t$ table was 3,012 it turned out that the result was 3,012 greater than 1,220 or the $t$ table was greater than or equal to $t$ arithmetic so that $\mathrm{HO}$ was accepted or there was no significant effect between daily growth and the type of feed. Calculation of the growth rate of fish is very important in aquaculture activities. The higher the growth rate of fish, the faster the fish will reach harvest. If the harvest period is faster, the cost of maintaining fish can be reduced so that the profits obtained will be greater. The slow growth rate of fish will slow down the harvest period so that it will increase production costs (maintenance costs and feed costs). The slow growth rate of fish will certainly reduce the profits to be obtained.

Based on the graph, the best value was in treatment P2 (1.25\%) followed by treatment P0 $(0.67 \%)$ then in treatment P2 $(0.37 \%)$ and treatment P3 $(0.34 \%)$. The efficiency of feed utilization shows how much is utilized for growth. Based on the results of the study, the 
Journal of Fish Health Vol. 1 (2) - Dec 2021

Aslamiah et al. (2021)

https://doi.org/10.29303/jfh.v1i2.533

addition of ciplukan leaf extract in feed was able to provide a significant increase in the efficiency value of feed utilization. However, the efficiency of tilapia feed utilization with the addition of $8 \%$ ciplukan leaf extract (P2) has a feed utilization efficiency value which tends to be higher than the other treatments. This indicates that the feed consumed with the addition of $8 \%$ ciplukan leaf extract (P2) is easily digested and utilized efficiently by fish.

Low feed efficiency values indicate that fish need more feed to increase their body weight. Only a small part of the feed energy is used for growth. Most of the energy from food is used for maintenance, the rest is for activity, growth, and reproduction (Haryanto et al., 2014). According to Handajani and Widodo (2010), factors that influence food on growth include physiological activities, metabolic processes and digestibles that are different for each individual fish. If the protein energy level of the feed exceeds the requirement, it will reduce consumption so that the uptake of other nutrients will decrease. Therefore, it is necessary to have the right balance between energy and protein in order to achieve efficient and effective use of feed (Putranti et al., 2015) .

Water quality measurements were carried out twice during the study, namely at the beginning and at the end of the study. The increase and decrease in temperature, $\mathrm{pH}$ and oxygen content were not very significant because the rearing medium was a controlled container. In table 4 . The temperatures in all treatments ranged from $28.2-31.0^{\circ} \mathrm{C}$. The temperature of the rearing media did not show a significant difference. This was because the factor that affected the temperature of the media water was the air temperature at that time and was not affected by the treatment given. According to Stickney (2000), the optimal living temperature of tilapia is in the range of $14^{\circ} \mathrm{C}-38^{\circ} \mathrm{C}$, naturally tilapia can spawn at a temperature of $22^{\circ} \mathrm{C}-37^{\circ} \mathrm{C}$, but a good temperature for breeding is around $25^{\circ} \mathrm{C}-30^{\circ} \mathrm{C}$, while temperatures that are too low $\left(6^{\circ} \mathrm{C}\right)$ and too high $\left(42^{\circ} \mathrm{C}\right)$ can kill cultured tilapia. Furthermore, it was stated that tilapia can still tolerate temperatures of $15^{\circ} \mathrm{C}$ and $37^{\circ} \mathrm{C}$. Wardoyo (1981) stated that the optimal temperature for fish growth lies between $25^{\circ} \mathrm{C}$ and $27^{\circ} \mathrm{C}$ and even fish appetite decreases when the water temperature increases. Based on the data above, the water temperature of the cultivation media during the activity tends to increase. This is because during the study the air temperature was getting higher due to the sunny weather. The high media temperature causes the metabolic process in tilapia to increase so that the need for oxygen (O2) increases. According to Anugraha et al., (2014) an increase in temperature of $10^{\circ} \mathrm{C}$ can cause an increase in metabolism of 3-5 times. At low temperature conditions will affect the immune system, while at high temperatures will accelerate fish exposed to bacterial infections. If the temperature drops suddenly there will be degeneration of red blood cells so that the respiration process will be disrupted (Zidni et al., 2017). Temperature can affect the eating activity of fish, an increase in temperature can affect the metabolic activity of fish, the higher the temperature, the faster the waters will experience oxygen saturation (Asmawi, 1983 in Leunufna, 2012).

Oxygen content is one of the important environmental factors for fish life. If the dissolved oxygen concentration is low, the appetite of the kept organisms will decrease, which will affect growth. Dissolved oxygen (DO) content in this study ranged from 6-7.5 mg/l. This value is still considered optimum for tilapia. This opinion is in accordance with research conducted by Suminar (2010) in Sumantry (2012) which states that oxygen levels of less than $4 \mathrm{mg} / \mathrm{l}$ will cause unfavorable effects for almost all aquatic microorganisms and oxygen levels of less than $2 \mathrm{mg} / \mathrm{l}$ can result in fish death. This is in accordance with Boyd's (1998) opinion that the dissolved oxygen concentration of $5 \mathrm{mg} / \mathrm{l}$ - saturation is the best condition for growth, while the dissolved oxygen concentration above saturation can be dangerous if 
Journal of Fish Health Vol. 1 (2) - Dec 2021

Aslamiah et al. (2021)

https://doi.org/10.29303/jfh.v1i2.533

supersaturation conditions occur in the entire volume of the pond. Where dissolved oxygen is needed for respiration, the process of burning food, swimming activities, growth, reproduction, and others.

The degree of acidity $(\mathrm{pH})$ in this study ranged from 7-8.5. This $\mathrm{pH}$ range is a good condition for the habitat and growth of tilapia. According to Sherif (2009), the pH range for optimal growth occurs at $\mathrm{pH} 7-8$. However, the $\mathrm{pH}$ value of 6.7 is still feasible for the growth and survival of tilapia fry with a size of $3-5 \mathrm{~cm}$.

\section{CONCLUSION}

From this study it was concluded that the addition of ciplukan leaf extract with different doses to feed did not significantly affect the absolute weight growth, survival rate, daily growth rate and feed utilization efficiency. However, the addition of ciplukan leaf extract with a concentration of $8 \%$ in the feed gave a survival rate of $(83.33 \pm 0.98)$, absolute weight growth of $(37.39 \pm 20.33)$, daily growth rate of $(1.25 \pm 0.60)$, and feed utilization efficiency $(4.67 \pm 0.58)$ and tended to be higher than the other treatments.

\section{ACKNOWLEDGMENT}

On this occasion, the author expresses his gratitude to the Aquaculture Study Program, University of Mataram, which has facilitated so that this research can be carried out.

\section{REFERENCES}

Anugraha, R, S., Subandiyono, \& Endang, A. (2014). Effect of Use of Pineapple Extract on Levels of Feed Protein Utilization and Growth of Carp (Cyprinus carpio). Journal of Aquaculture Management and Technology, 3 (4), 238-246

Ekubo, AA, \& JFN Abowei., (2011). Review of Some Water Quality Management Principles in Culture Fisheries. Research Journal of Applied Sciences, Engineering Technology, 3(12), 1342-1357.

Effendi, MI (1997). Experimental Design Method. CV Armico. Bandung. 472 p.

Handajani, H., \& Wahyu, W. (2010). Fish Nutrition. Malang: UMM Press.

Haryanto, P., Pinandoyo., \& Restiana, WA (2014). Effect of Different Artificial Feed Doses on Juvenile Growth of Tiger Grouper (Epinephelus fuscoguttatus) . Journal of Aquaculture Management and Technology, 3(4), 58-66.

Heyne, K. (1987). Useful Plants of Indonesia.vol. 3:1502-1503 Trans. Sarana Wana Jaya Foundation. Jakarta.

Halver J E. (2002). Fish Nutrition. Third Ed. Academic Press. New York. 822 pp

Jyothibasu, T. \& Venkata, RK (2014). Pharmacological Review OnPhysalis Species: A Potential Herbal Care-All. World Journal of Pharmaceutical Research. 4(2): 247-256.

Khairuman \& K. Amri. (2003). Intensive Tilapia Cultivation. Agrimedia, Jakarta.

Kordi, MGH., \& AB Tancung. (2005). Water Quality Management in Aquaculture. Publisher Rineka Cipta. Jakarta.

Kurniawan, (2013). The Effect of Tin Mining Activities on the Quality of Seawater and the Quality of Red Snapper (Latjanus campechanus) Caught in the Coastal Area of Bangka Regency, Bangka Belitung Islands Province. Thesis. Master's Degree in Coastal and Coastal Resource Management, Diponegoro University. 
Journal of Fish Health Vol. 1 (2) - Dec 2021

Aslamiah et al. (2021)

https://doi.org/10.29303/jfh.v1i2.533

Lenny, S. (2006). Flavonoid Compounds, Phenyl Propanoida and Alkaloids. MIPA, University of North Sumatra.

Nayak, SK (2010). Probiotics and immunity: a fish perspective. reviews. Fish and shellfish immunology 2(9): 2-14.

Ningrum, R., Elly, P., \& Sukarsono. (2016). Identification of Alkaloid Compounds from Batang Karamunting (Rhodomyrtus tomentosa) as Biology Teaching Materials for Class X SMA. Indonesian Journal of Biology Education, 2 (3), 231-236.

Noga, EJ (2010). Fish Disease Diagnosis and Treatment. lowa State University Press. A Blackwell Publishing Company.

Oliveira, JGD, \& Angela, PV (2011). Papaya: Nutritional and Pharmacological Characterization, and Quality Loss Due to Physiological Disorders. Food Research International. 44(1), 1306-1313.

Pasaribu, W., Sammy, NJ, Longdong, \& Joppy, DM (2015). The effectiveness of water henna leaf extract (Impatiens balsamina L.) to increase the non-specific immune response of tilapia (Oreochromis niloticus). Journal of Aquaculture, 3(1), 83-82.

Permana, RB (2013). Anti-diabetic activity of Ciplukan Fruit (Physalis angulata Linn.) in Type-2 Diabetes Mellitus Model Rats. [Thesis]. Department of Biochemistry. Faculty of Mathematics and Natural Sciences. Bogor Agricultural Institute.

Pillai, TVR (1995). Aquaculture: Principles of Practice. Fishing News Books, Oxford. PP:3344347.

Rohyani IS, et al. (2015). Phytochemical content of several types of local plants that are often used as raw materials for medicine on the island of Lombok. Biology Study Program, Faculty of Mathematics and Natural Sciences, University of Mataram. Pages: 388-391.

Stickney, RR (2000). Tilapia culture. Encyclopedia of Aquaculture.A Wiley-Interscience Publication. p. 934-941.

Salgado, Elsa Rengifo, \& Gabriel Vargas Arana. (2013). Physalis angulata L. (Bolsa Mullaca): A Review of its Traditional Uses, Chemistry and Pharmacology. www.revistas.usach.cl. accessed 8 April 2014.

Trewavas E. (1982). Tilapia Taxonomy and Specifications. In: Pullin, RSV and Lowe-Mc-Connel, $\mathrm{RH}$ (eds) The biology and culture of Thilapias. ICLARM, mania, the Philippines, pp. 314. 